\title{
Competing Interests in State Supreme Courts: Justices' Votes and Voting Rights
}

\section{Scott Graves}

The presidential election of 2000 put a spotlight on the substantial opportunities for judicial involvement in the electoral process and the potential for partisan and ideological preferences to conflict in judicial choices. Building on recent scholarship analyzing the influence of institutions and preferences on state supreme court decision-making, I hypothesize that in cases involving voting rights decisions the partisan affiliation of justices rather than ideology contributes to justices' voting behavior. Using data from the State Supreme Court Data Project and other data, I test the comparative influence of traditional left-right ideology and alignment with the dominant party of the state on ballot access cases. I find evidence that partisanship does matter to justices in ballot access cases, conditional on the method of judicial selection.

The legal cases resulting from the 2000 presidential election and the widespread belief that the contest was ultimately decided by the Supreme Court's decision in Bush v. Gore (121 S Ct 525) have brought considerable attention to the little-known role that the judiciary plays in administering our electoral process. As demonstrated by the variety of complaints filed in late 2000 , courts must at times interpret statutes and regulations governing the design of ballots, the admissibility of votes, the handling of absentee ballots, and the conduct of recounts. ${ }^{1}$ In addition, state courts hear challenges to the ballot access decisions of election officials regarding primary and general election candidacies and popular initiatives and referenda. All told, the involvement of courts with electoral processes is extensive.

An interesting result of the Bush v. Gore decision was to highlight the distinction between policy preferences and partisanship as influences on judicial behavior. As many critics noted, the federal Equal Protection claim against Florida's high court upon which the majority acted in Bush v. Gore was not an argument many would have predicted to find a sympathetic ear in Justices Scalia, Rehnquist, and Thomas (Gillman 2001, pp. 161-62). The preeminence of the "attitudinal model" in judicial politics scholarship has made policy preferences a primary explanation for decision-making in courts (Segal and Spaeth 1993), but in cases directly involving elections and party politics, we can easily imagine conflicts between the policy preferences of

I would like to thank Paul Brace and Laura Langer for generously providing data and Jeff Segal and the anonymous reviewers and editor for helpful suggestions and advice. Any remaining errors are my own.

SCOTT GRAVES is Assistant Professor of Political Science at Georgia State University.

The American Review of Politics, Vol. 24, Fall, 2003: 267-283

(C)2003 The American Review of Politics 
judges as typically understood and the consequences represented by political outcomes (Lloyd 1995). In Bush v. Gore, this conflict is reflected in the choice of the justices to vote in favor of vacating a state court decision on Equal Protection grounds or to let candidate Gore's contest of the election returns favoring candidate Bush continue.

Of course, the vast majority of judicial activity in electoral politics occurs below the U.S. Supreme Court, primarily in the states. Quantitative studies of state courts, even appellate courts, is significantly younger than those of the Supreme Court, but the literature on the policymaking role of state supreme courts ${ }^{2}$ and the determinants of state judicial decision making has advanced considerably in recent years (Brace and Hall 1992; Glick 1999; Brace, Langer, and Hall 2000; Brace and Hall 2000). Distinguishing partisan and ideological influences on the behavior of judges below the Supreme Court has been impeded in the past by the widespread use of party affiliation to measure ideology (Tate 1981; Songer and Davis 1990). Fortunately, many of the scholars involved in advanced quantitative analyses of state courts have done considerable work to collect new data on state court outputs, their institutional contexts, and the individuals who sit upon them. Using the preliminary release of data from the State Supreme Court Data Project (Brace and Hall 2001) and additional data on state court justices' ideology (Brace, Langer, and Hall 2000), I seek to test the relative influence of ideological and partisan politics on the judicial voting in ballot access cases before state supreme courts within the context of the varying institutional settings of high courts in the states.

\section{Ballot Access Politics and Policymaking on High Courts}

Judicial protection and regulation of voting rights and access to the ballot have been subjected to study before, especially at the U.S. Supreme Court level. McCleskey (1984) found that postwar Supreme Court decisions regarding ballot access regulation in the states had served to enhance the role of political parties in democratic politics. Epstein and Hadley (1990) report that minor political parties resort to litigation more often than major parties, consistent with their expectation that minority interests make more extensive use of the courts than do more politically successful ones, but that the Supreme Court does not afford minority parties special treatment or inordinate success. Much of the litigation and decision-making about ballot access takes place in the state courts, however, and analysis of voting rights protection should incorporate the policymakers whose decisions are often the final word on ballot access questions.

It is no longer rare to find students of judicial decision-making who consider judges to be motivated by policy goals. In fact, analysts of the 
United States Supreme Court have been investigating the relationships between policy motives and outcomes of justices' decisions for decades and have made considerable progress (Pritchett 1948; Schubert 1965; Segal and Spaeth 1993). The state supreme courts have also been subject to study as important policymaking bodies. State supreme courts are the courts of last resort in most cases within their jurisdiction and their collective caseloads easily dwarf the number of cases decided by the Supreme Court in a given period of time (Glick 1991). Furthermore, like federal appellate courts, state supreme courts create rules of legal procedure that guide the administration of law for lower state courts, who handle the bulk of litigation in the United States, and these rules can have substantial impacts on the outcome of cases (Glick 1982; Jacob 1996).

Not surprisingly, scholars have used state supreme courts and states to focus attention on the consequences of institutional, economic, and political differences that can be found from one state to another. Atkins and Glick (1976) found that courts in industrialized, politically competitive states handled a larger number of civil liberties cases. Some of the most sophisticated research of the last decade has focused on the effects of judicial selection mechanisms (Brace and Hall 1990; Brace and Hall 1997; Hall 2001). The political context of state supreme court justices, elected or appointed and in what way, has been found to affect not only the distribution of preferences apparent on the high courts but also the transformation of those preferences into voting behavior. Following attitudinal research at the national level, studies have found that measures of policy preferences offer reliable predictions of the votes of state supreme court justices (Brace, Langer, and Hall 2000). Scholars have also tested the effects of institutional features of the judiciary on the formation and manifestation of justices' preferences through voting behavior (Brace and Hall 1997).

Voting rights jurisprudence in the states attracts interest for a variety of reasons. The events leading up to the Supreme Court's Bush v. Gore decision ending the 2000 presidential election contest was accompanied by claims of partisan bias at state and local levels within and outside the courts and by both sides. Also, as was clear in that case, electoral issues implicate preferences and incentives of policymakers that are both ideological and partisan, often diametrically opposed to one another. We can imagine justices, especially those who attain their seats through partisan elections or political appointment, being pulled in opposite directions by their legal principles and their loyalty to political groups or actors. Also, the different selection mechanisms used to staff the high courts of the states might have different effects on decision-making through the way they tie the justices to the party systems in the state. 


\section{A Model of State Supreme Court Ballot Access Votes}

To test hypotheses on the effects of various factors on voting rights decision-making on state high courts, I develop a model of individual justices' votes in ballot access cases. Typically, ballot access cases confront justices with an opportunity either to expand the choices presented before the public in elections or to restrict those choices. As McCleskey (1984) points out, state interest in regulating ballot access is in preventing confusion in the mind of voters faced with a ballot. At times, justices have found such purpose served by limiting the number of choices in elections or preventing items from being voted upon by initiative or referendum. Decisions expanding ballot access, increasing or failing to restrict choices on ballots, have the potential to change the political status quo. Also, ballot access decisions challenged in court are typically made by actors of the dominant political party of the state (election commissioners, secretaries of state, etc.). In this study, I examine whether these decisions to limit or increase the choices available to voters through the ballot made by individual justices are conditioned in any way by the manner in which justices are selected, the political context of the state, or the personal ideology or partisanship of the justices.

A once-healthy tradition in public law scholarship, often linked with Cortner (1968) and the case-study literature of civil rights litigation, held that many of the most successful interest-group litigation campaigns were the work of politically disadvantaged groups. Politically disadvantaged groups were believed to depend on the judicial process to overcome those disadvantages, and courts were believed to be especially receptive to the claims of "outsider" or marginalized social and political groups. Scholars have also noted the institutional capacity of the Supreme Court to protect minority interests and the integrity of the political process (Epstein and Hadley 1990). ${ }^{3}$ In the past two decades, the so-called "political disadvantage" theory has fallen into disfavor, with critics demonstrating that groups of many types use litigation and that courts are not especially prone to favor the disadvantaged (Olson 1990; Scheppele and Walker 1991; Songer and Sheehan 1992; Sheehan, Mishler, and Songer 1992).

Recent scholarship finds the discrediting of the political disadvantage theory "dubious" (Coglianese 1998). This response has sought to reformulate the political disadvantage theory to explain the advancement of "longshot" cases and innovative legal arguments by groups who lack other alternatives and resources. Coglianese suggests that quixotic litigation by politically disadvantaged groups often seeks to change the rules of the political games in which they cannot compete, like efforts to challenge ballot decisions. This formulation seems particularly apt to court cases challenging denials of ballot access to parties who lack significant representation in public offices. 
An orthodox version of the political disadvantage theory suggests that justices seeking to protect the interests of political minorities and the disadvantaged should be more likely to vote in favor of expanded ballot access. Literature critical of political disadvantage theory, especially noting the observed tendency of courts to rule for "upperdogs" and against "underdogs," leads to the opposite conclusion. If we believe that the vast majority of ballot access litigation is sponsored by politically marginalized actors it follows that the underlying propensity of justices to vote for or against expanded ballot access indicates the force of political disadvantage in judicial decision making. Coglianese's re-conception of political disadvantage theory leads us to expect that many if not most of the ballot access cases brought to the high courts should be weak, novel, "long shot" arguments and thus should be more likely to fail.

Following previous research (Brace and Hall 1997) I expect that the method of selecting justices for high courts in the states should have an effect on their ballot access decisions. However, that effect should be conditional on their partisan affiliation and the party dominance of the state as well. States use four different methods to choose justices: partisan elections, non-partisan elections, government appointment, and merit selection (Glick 1999). Government appointment methods include systems using sole appointment by governor, legislative appointment, and gubernatorial nomination and legislative confirmation. The methods of judicial selection and reappointment used by each state in this study during the period (1995-1996) are presented in Table 1.

The selection mechanisms for justices differ in the degree to which they are alleged to bind the justices to the political and party systems of their states. According to advocates of judicial selection reform, government appointment produces the least independent judiciary, followed by partisan elections (Hall 2001). This literature also indicates that use of non-partisan

Table 1. Judicial Selection Methods of the States in the Study (1995-1996)

\begin{tabular}{|c|c|}
\hline Method of Selection & States \\
\hline Merit Commission & $\begin{array}{l}\text { Alaska, Arizona, Colorado, Connecticut, Hawaii, Iowa, } \\
\text { Maryland, Massachusetts, Missouri, New Mexico, } \\
\text { New York, Oklahoma, Rhode Island, South Dakota }\end{array}$ \\
\hline Non-partisan Election & Kentucky, Minnesota, Montana, Oregon \\
\hline Partisan Election & Arkansas, Ohio, Texas, West Virginia \\
\hline Government Appointment & Maine, South Carolina \\
\hline
\end{tabular}


elections and merit selection committees create an independent judiciary more likely to resist control or influence of political and partisan pressures. Hall argues that the insulation of non-partisan elections from partisan politics is likely overstated (2001). Nevertheless, I expect that non-partisan elections will exhibit less party-identification effect on justices' ballot access votes and merit committee selection the least of all.

While the effect of selection method on individual justices' votes should vary in magnitude, the direction of influence will depend on the political party affiliation of the justice and the political party of the government. Specifically, justices who share the partisan affiliation of the dominant state party should be less likely to vote in favor of expanded ballot access, while justices whose party identity is opposed to the dominant party in state government should be more likely to vote for ballot access rights. This expectation assumes that, on average, decisions rejecting ballot access requests tend to favor the dominant party of the state. ${ }^{4}$ Again, the specification suggests an interactive effect of partisan affiliation of the justice and state and the selection methods that produce different degrees of partisan influence.

Individual policy preferences, or ideologies, are widely believed to influence judicial choices, especially when judges face fewer hierarchical and institutional constraints (Segal and Spaeth 1993; Songer and Sheehan 1992). More students of American institutions are including ideology or policy preferences in their empirical models in recent years due not merely to theoretical changes but because, as Brace, Langer and Hall state, "political science appears to be in the midst of a small but important revolution in the study and measurement of preferences" (2000). Effective study of many questions, including the relative significance of policy preferences and institutional and contextual effects on elite decisions, depends on reliable estimation of policy preferences. The increasingly sophisticated analysis of votes to estimate ideal points and (in some cases) confidence intervals for legislative and judicial actors' preferences improves our understanding of the ideological placement of policymakers, but has yet to succeed in isolating preference from other systematic effects. ${ }^{5}$

In this instance, a powerful element of personal interest may be captured by the partisan affiliation of the justices, operationalized as the coincidence of the justices' party of affiliation and the dominant party of the state polity. An effect of party affiliation so measured might affect judicial voting in election cases in place of ideological preferences, rather than as a proxy for them. However, given the strong association of most legal doctrines that advocate expansion of voting rights with liberal politics and ideologies, a measure of the justices' liberalism must be included as a control. According to conventional wisdom, a more liberal justice should, all else equal, be 
more likely to vote for expanded ballot access than a justice who is less liberal. $^{6}$

\section{Data and Methodology}

My primary data come from the State Supreme Court Data Project (Brace and Hall 2001). The dataset contains all cases decided by courts of last resort in each of the 50 states if the court in question decides fewer than or equal to 200 cases and a random sample of 200 cases from those issuing more than 200 formal opinions (signed or per curium) for the years 1995 and 1996. From this set of cases, I identified those falling into the Civil Government category and selected from those the decisions in which a ballot access claim was at issue. ${ }^{7}$ I decomposed this set of 80 cases into the individual votes of the state supreme court justices resulting in 484 observations. Because the state supreme court database codes outcomes in regard to whether the petitioner or respondent wins the case, rather than according to an ideological scheme, I derived the dependent variable, whether the justice voted for or against expansion of ballot choice in a given case, from analysis of the outcome variables and identity of the parties. Cases where the justice voted in favor of the party wishing to extend ballot access were coded 1 while contrary votes were coded 0 . I examined the written opinions to double-check that the coding logic accurately reflected the outcomes of the cases and to code isolated cases that could not be deduced from the outcome variables. The resulting dataset includes 449 valid observations from 24 states. ${ }^{8}$

Using the raw case data, I calculated a variable, called Unanimous, denoting which cases were decided unanimously. If significantly different from zero, the direction of this variable will indicate whether state supreme courts have a general propensity to favor or disfavor ballot access claims. On its face, the unanimous variable suggests cases that are particularly strong (if successful) or weak (if unsuccessful), thus a significant negative coefficient for its effect suggests that the ballot access cases tend to be without merit, while a positive coefficient suggests that justices tend to be invariably receptive to ballot access claims. No significant effect suggests that these courts are not receptive or hostile to the claims of the disadvantaged.

Using data generously supplied by Laura Langer and supplemental searches via Lexis/Nexis regional newspapers, I added the party identification of justices to the case data. In addition, I collected the Ranney index of interparty competition and control of government data, updated to 1998, from Bibby and Holbrook (1999). Bibby and Holbrook report the original Ranney party control index, which measures degree of Democratic dominance $(0-1)$. From this data I identified whether the Ranney index reflects Democratic or Republican control (splitting the index in the middle) and used it to designate whether each justice shared affiliation with the dominant 
party in government. A dichotomous variable identifying whether the justice is of the dominant party in government (1) or not (0) is called Same Party. ${ }^{9}$

To estimate the effects of the selection mechanisms used in the states I generated indicator variables for three of the four systems in use. I determined the selection systems in use by each state from Hall (2001) and the website of the American Judicature Society. ${ }^{10}$ The merit commission is the most common system and also the selection mechanism believed to be least likely to generate the identification between justices and their political parties, so it was chosen as the excluded "baseline" category. Dichotomous variables indicate whether each justice is selected by partisan election (Partisan), non-partisan election (Non-Partisan), or by government appointment (Government).

Theory suggests several interactive effects, specifically between the Same Party indicator and selection mechanism identifiers (Partisan, NonPartisan, and Government). For each variable, I generated a new variable by multiplication with the dichotomous Same Party. The variables SP-Partisan, SP-Non-Partisan, and SP-Government are dichotomous variables reflecting whether the justice is of the dominant party and is selected in the indicated manner. The result of adding these variables is to estimate the separate effect of these conditions when the justice is also of the dominant party. Thus, the coefficients associated with the main effects (Partisan, Non-Partisan, and Government) will reflect influence on justices' voting regardless of partisan identification while the interactive effects indicate influence when the dominant party in the state is the same as the justice's identification. Likewise, the constituent term Same Party will reflect primarily the effects of shared party identification when the judge is selected via a merit system.

In the context of state supreme courts, various problems have arisen in the most common methods of measuring personal ideology, reviewed in Brace, Langer, and Hall (2000). As indicated above, using past votes and cumulative scaling techniques threatens to subsume other explanatory factors into estimations of preferences. Political party affiliation, useful distinctions for many purposes, does not offer a great deal of breadth in terms of preference estimation, nor can it accurately reflect the differences between political parties from one state to another. Brace, Langer, and Hall (2000) present a measure of policy preferences on a liberal-conservative dimension based on the state elite and citizen ideology scores developed by William Berry and associates (1998) and the partisan affiliation of the justices. This measure, which they dub party-adjusted judge ideology (PAJID), provides an interval-level scale of political liberalism, and proves to be stable across time and to have impressive predictive power. I expect that more liberal justices will be more likely to vote in favor of ballot access, or not to limit choice in a given ballot access decision. 
Table 2. Descriptive Statistics and Hypothesized Direction of Effects for Covariates

\begin{tabular}{lrrrrrc}
\hline & \# Obs & Mean & Std.Dev. & Min & Max & Ex. Dir. \\
\hline Ballot Access vote & 449 & .481 & .500 & 0 & 1 & na \\
Unanimous & 449 & .601 & .490 & 0 & 1 & $+/-$ \\
PAJID & 449 & 46.285 & 22.393 & 1.79 & 97.07 & + \\
Same Party & 449 & .365 & .482 & 0 & 1 & $+/ 0$ \\
Non-Partisan Election & 449 & .325 & .469 & 0 & 1 & + \\
Partisan Election & 449 & .149 & .357 & 0 & 1 & + \\
Government Appointment & 449 & .047 & .211 & 0 & 1 & + \\
SP*Non-Partisan & 449 & .082 & .275 & 0 & 1 & - \\
SP*Partisan & 449 & .085 & .279 & 0 & 1 & - \\
SP*Government & 449 & .018 & .132 & 0 & 1 & - \\
\hline
\end{tabular}

Descriptive statistics for all variables used in the analysis are presented in Table 2. Also, the table indicates the expected direction of the effect of the variable on the likelihood of a vote for expanded ballot access. Due to the dichotomous nature of the dependent variable, I use logit regression to model the justices' votes $(Y)$ as a function of a set of explanatory variables $(X) .{ }^{11}$ The functional form of the logit model is:

$$
\operatorname{Prob}(\mathrm{Y}=1)=\frac{e^{\beta^{\prime} X}}{1+e^{\beta^{\prime} X}}
$$

A primary concern of hypothesis tests using justices' vote data pooled from many states is the likelihood of positively correlated errors between observations from the same state. Any misspecification of common factors affecting votes on the same court will result in understatement of the variance estimates for the logit parameters (more formally, the variance estimates are inconsistent due to heteroskedasticity). With overly optimistic standard errors, the likelihood of Type I error, or false positive results, increases. To deal with this problem, I calculated robust standard errors clustered on the state of origin. ${ }^{12}$ The variance estimator for the clustered data is specified (Greene 2000; Beck 1996):

$$
V a r_{\text {clustered }}=\left(X^{\prime} X\right)^{-1} \sum_{j=1}^{N_{C}}\left[\left(\sum_{i=1}^{n_{j}} e_{i} x_{i}\right)\left(\sum_{i=1}^{n_{j}} e_{i} x_{i}\right)\right]\left(X^{\prime} X\right)^{-1}
$$

Where $N_{C}$ is the number of clusters, $n_{j}$ is the number of observations within a given cluster, $j$ is a particular cluster, and $i$ designates an individual observation within a cluster (state). The variance estimator bases the standard errors on the information within clusters, rather than assuming independence across clusters. Although these standard error estimates will 
be consistent in the presence of heteroskedasticity, they are likely to be less efficient, since the variance is based on considerably smaller samples than the point estimates of the coefficients $(\hat{\beta})$.

\section{Results and Discussion}

The results of an estimated logit equation of the state supreme court justices' ballot access votes on the explanatory covariates appear in Table 3 . As a test of the model fit, I calculated the proportion of the error made by predicting the modal category reduced by the estimated model at 0.279 . Votes against ballot access outnumber votes in favor, 233 to 216 , so the modal prediction is correct approximately 52 percent of the time. The full model predicts 292 or more than 65 percent of the cases correctly.

The coefficient for Unanimous, cases decided without dissents, is negative and significant. Although votes against ballot access expansion outnumber votes in favor in the dataset, the difference in their number is not nearly great enough to predict the clearly significant negative effect of unanimously decided cases. State supreme court justices are much more likely to agree without exception to reject a ballot access claim than to accept one. We can conclude from this either that state supreme court justices are, on average, disinclined to look favorably on pleas for expanded ballot access, contradicting the traditional political disadvantage theory, or that many of the cases brought by parties seeking to expand ballot access are bad, "long shot"

Table 3. Logit Model of Ballot-Access Votes (DV = Vote to Extend Ballot Access)

\begin{tabular}{lclr}
\hline & $\beta$ & SE* & Z-score \\
\hline Unanimous & -0.681 & 0.260 & -2.62 \\
Judge Ideology & -0.0119 & 0.00880 & -1.36 \\
Same Party (SP) & -0.158 & 0.445 & -0.36 \\
Non-Partisan Election & 1.155 & 0.358 & 3.22 \\
Partisan Election & 0.384 & 0.886 & 0.43 \\
Government Appointment & 2.193 & 1.379 & 1.59 \\
SP*Non-Partisan Election & -0.916 & 0.545 & -1.68 \\
SP*Partisan Election & -1.086 & 0.985 & -1.10 \\
SP*Government Appointment & -1.701 & 0.498 & -3.42 \\
Constant & 1.838 & 1.766 & \\
*Robust Standard Errors clustered on States & & & \\
N=449 & & & \\
$\chi^{2}(8)=49.669 ; p<0.000$ & & & \\
Proportion of Error Reduced: 0.279. & & & \\
\hline
\end{tabular}


cases. The first reading of these results may indicate some judicial restraint in election cases. The second interpretation supports Coglianese's (1998) conjecture that politically disadvantaged parties are more likely to bring claims to court without regard to their likelihood of winning.

The coefficients for judicial ideology (PAJID) and for shared party identification of the justice and the state government (Same Party) are opposite of their predicted direction, but statistically insignificant. The insignificance of judicial ideology suggests that ballot access decisions are not of a kind that reflects a clear ideological predisposition along the traditional liberal-conservative dimension. Because the Same Party variable is also interacted with the selection mechanism variables, the coefficient for its main effect evaluated here reflects the ceteris paribus impact of justices in the excluded category, merit commission, who are affiliated with the dominant party against the baseline of merit selected justices from the opposing party. Given the expectation that merit selection would not create strong associations between justices and their parties, the lack of significance is not surprising, even if the direction of the coefficient is.

All of the remaining coefficients are in expected directions and several are significant at conventionally acceptable levels. The set of indicators for justice selection mechanisms all carry positive coefficients, as anticipated since the effects of these systems when the justice is of the dominant party of the state are estimated separately. The latter are all negative, also as expected. Of these coefficients, Non-Partisan and SP*Government Appointment are significant at the .001 level, SP*Non-Partisan is significant at the .05 level, and Government Appointment is very close to significance at that level (using one-tailed tests). The coefficients for Partisan, the variable indicating justices chosen in party elections, and its interaction with Same Party are indistinguishable from zero. The lack of effects for partisan elections is curious, suggesting that justices elected with party labels are no more or less likely to vote for expanded ballot access regardless of their affiliation with the dominant party.

The substantive impact of the variables in the model is difficult to assess from the logit coefficients. Therefore, in Table 4 I present predicted probabilities of a vote to expand ballot access for various reasonable values of the covariates. The probabilities also have confidence intervals reflecting the standard errors of the coefficient estimates. Since many of the variables are mutually exclusive or interactive ${ }^{13}$ care must be taken in setting the variables to sensible, observable values. As a baseline, I estimate a prediction with all variables set at their median values, which are also the modal values for dichotomous covariates. The baseline model represents the vote of a merit-selected justice with PAJID of 48.33 who is not of the dominant party of the state in a unanimously decided case. ${ }^{14}$ The predicted probability of a 
Table 4. Predicted Probabilities of Voting to Expand Ballot Access*

\begin{tabular}{lccc}
\hline Settings & $P(Y=1)$ & \multicolumn{2}{c}{$95 \%$ CI } \\
\hline All Variables at Median/Modal values & 0.324 & 0.227 & 0.439 \\
Non-unanimous cases** & 0.487 & 0.357 & 0.618 \\
Government Appointment, Same Party & 0.569 & 0.050 & 0.971 \\
Government Appointment, Not Same Party & 0.895 & 0.368 & 0.992 \\
Non-Partisan Election, Same Party & 0.507 & 0.253 & 0.757 \\
Non-Partisan Election, Not Same Party & 0.751 & 0.639 & 0.837 \\
Partisan Election, Same Party & 0.286 & 0.060 & 0.718 \\
Partisan Election, Not Same Party & 0.582 & 0.224 & 0.871 \\
*Predicted probabilities estimated using S-Post commands. & & \\
**All estimates after this point assume non-unanimous cases (Unanimous = 0); all other variables \\
not specified are set at their median/modal values. \\
\hline
\end{tabular}

vote for expansion of ballot access $[P(Y=1)]$ is 32.4 , with a 95 percent confidence interval bounded by 22.7 and 43.9 .

Thus, the statistically average case is not likely to elicit a vote in favor of extending ballot access from the statistically average judge. However, if we assume that unanimous cases are primarily long shot or frivolous, then our attention is better focused on the more substantively interesting nonunanimous cases. Changing the Unanimous variable from 1 to 0 to reflect a split-vote case causes the probability of a pro-ballot access vote to rise, all else held constant, to 48.7 percent, with an interval from 35.7 to 61.8 . Not only is the estimated probability very close to even, the cutoff probability of 50 percent is well within the confidence interval. Thus it appears that merit selected justices hearing non-trivial appeals for expanded ballot access are fairly receptive to such appeals. The Same Party variable is not statistically significant, leading us to infer that this is true regardless of the justices' alignment with the political control of the state.

I hold Unanimous at 0 for the remaining predictions. Despite its lack of statistical significance, I manipulate the shared party identification variable as well as the selection mechanism indicators in order to evaluate their interactions. The next estimate in Table 4 assumes a justice appointed by and sharing party affiliation with the state government. Such a justice is predicted to vote in favor of expanded ballot access with 56.9 percent probability, although the confidence interval encompasses most of the possible range. A government appointee who is not of the dominant party in government has nearly a 90 percent likelihood of voting to expand ballot access, however, and the lower bound of the confidence interval is 36.8 percent.

The remaining hypothetical cases examine the predicted behavior of competitively elected justices. Justices chosen through non-partisan 
elections who are of the same party as the state government are predicted to have a roughly even likelihood of voting to expand ballot access in split vote cases, but those who are not of the dominant party in state government are estimated to vote in favor of ballot access with 75.1 percent probability and a confidence interval that comfortably excludes the 50 percent cutoff point. By comparison, justices subject to partisan elections have an estimated 28.6 percent likelihood of voting to extend ballot access if they share party affiliation with the state government and 58.2 percent if they do not, but both estimates have large confidence intervals as one would expect given the standard errors on the coefficients.

The predicted probabilities demonstrate the significance of selection mechanisms to partisan behavior. Justices chosen via merit selection are almost as likely to vote in favor of expanding ballot access as against it regardless of partisan incentive, according to the model predictions. Those who run in non-partisan elections demonstrate the next smallest difference across partisan alignments, increasing from 50.7 percent likelihood when of the same party to 75.1 percent when of the opposite party, but this is a substantial difference nonetheless. Although the coefficients were not significant and the estimated predictions are consequently not precise, partisan elections evoke a difference of nearly 30 percent depending on shared party identification. Justices appointed by the government in some fashion reveal a difference of more than 30 percent, supporting the hypothesis that such a method produces the least independent of judicial systems, although the electoral systems both evince a sizeable degree of partisan association.

\section{Conclusion}

Many of our most important political rights, including the rights that guarantee citizens a role in the selection of our governors and the rules by which we are governed, are entrusted to the judiciary for protection. Although the federal courts are actively involved in overseeing those rights, much of the actual decision-making in regard to political rights takes place in the state courts. The results of this study suggest that partisan interests have an impact on the choices that state supreme court justices make regarding political rights, conditional on the way in which the justices are chosen.

As predicted, justices appointed by the legislature or governor are the most strongly tied to their parties, compared to those chosen by competitive elections or the merit reform procedure. Non-partisan elections also produce an effect on justices, making them more or less likely to vote in favor of extending ballot access depending on their personal relationship with the dominant political party in the state. Although predicted probabilities suggest that partisan elections do tie justices' decisions to their party affiliations more than non-partisan elections, the coefficients for the variables were not 
statistically different from zero. Two possible interpretations of this finding are that partisan elections do not inject party politics into high court selection, or that the popular association of judges with parties resulting from partisan elections puts pressure on justices to avoid votes that appear too favorable to their own party label. Since non-partisan elections, according to these results, do appear to create associations with justices' parties (or perhaps, justices' party attachments appear to survive non-partisan elections) it seems the second explanation is more plausible.

Personal ideology, measured on a liberal-conservative dimension, does not have an identifiable impact on justices' ballot access votes. One possible reason for this finding is that the liberal-conservative dimension does not capture preferences regarding political rights. Put another way, political rights jurisprudence or at least ballot access choices may define a separate dimension, at least partly orthogonal to the traditional left-right dimension of social and economic politics. Another explanation, offered above, is that justices' preferences in election cases are more closely related to the political consequences of the decision for the justices' party, rather than an ideological commitment to expanding or restricting access. The use of political party for justices in this analysis cannot be considered a proxy for political ideology, because the variable indicates whether the justice claims affiliation with the dominant party of the state, as measured by the Ranney Index, rather than the nominal party label. The success of party affiliation in explaining variation in ballot access cases (conditional on selection method) while controlling for a preference measure that corresponds closely with traditional liberal-conservative legal principles suggests that ballot access cases are not decided on the basis of ideology or principle, but instrumentally.

Despite a near-even split between votes extending ballot access and votes denying it, votes in unanimous decisions were significantly more likely to deny ballot access. The partisan heterogeneity of state high court panels makes it seem unlikely that this is due to state courts comprised solely of one party voting together to deny ballot access to challengers, but due to the lack of detailed fact pattern data we cannot directly assess the individual merits of the claims brought by petitioners. Nevertheless, the frequency of unanimous denials of ballot access rights comports with the expectation of what might be called a revisionist political disadvantage theory: politically disadvantaged parties are more likely to bring formally frivolous claims in court without regard to the merit or likely success of the claims, especially when seeking to overcome the source of their political disadvantage. Confirmation of this interpretation awaits closer inspection of the cases brought before the courts. 


\section{NOTES}

${ }^{1}$ See Gillman (2001) for a detailed presentation of the myriad of judicial actions conducted during November and December of 2000.

${ }^{2}$ Following other scholars (Brace and Hall 1990; Glick 1982) I will use the terms "state supreme courts" and "state courts of last resort" interchangeably.

${ }^{3}$ See also Mason $(1956,511-12)$ on Justice Stone's famous footnote 4 to Carolene Products wherein he justifies heightened scrutiny of legislation affecting political processes and "discrete and insular minorities."

${ }^{4}$ Specifically, marginal candidates who are likely to draw support from the opposition party, "spoilers," are more likely to be permitted by election officials while those drawing support from the dominant party will not.

${ }^{5}$ See the special issue of Political Analysis devoted to preference estimation in spatial models, Vol. 9, No. 3.

${ }^{6}$ One can think of several instances, particularly reverse discrimination claims connected with minority-majority districts, when this expectation might be violated. Nevertheless, I expect that liberalism and expanded ballot access coincide more frequently than they conflict.

${ }^{7}$ Issue Classification $=2$; Ballot access $=1$. Several other voting rights categories were coded in the dataset, including apportionment/redistricting, contested elections, and campaign spending. Ballot access cases were the most numerous (apportionment $=5$; contested election $=41$; campaign spending $=6$ ) and the clearest to code in terms of their political consequences.

${ }^{8}$ Several cases were excluded from analysis due either to the presence of another dispository issue unrelated to ballot access or ambiguity in the opinion regarding the outcome. One case from Nebraska had to be dropped because the state has non-partisan legislative elections and thus, no "partisanship" to its government.

${ }^{9} \mathrm{I}$ also estimated a model similar to that presented below including the folded Ranney index, which measures the degree to which a state is dominated by one party without distinguishing which one and an interaction with the Same Party variable to see if justices respond to the degree of one-party dominance. Neither variable was significant and the other substantive results were essentially unchanged.

${ }^{10} \mathrm{http}: / /$ www.ajs.org/select11.html.

${ }_{11}^{11}$ All analysis was conducted using Stata 8.0.

${ }^{12}$ This was done using the cluster command in Stata, which calculates standard errors based on the Huber/White robust variance estimator and within-cluster information. Clustering on justices produces no substantive inferential differences.

${ }^{13}$ It makes no sense for a given vote to be affected by non-partisan election and government appointment (Non-Partisan $=1$ and Government Appointment $=1$ ) or for an individual justice to be of the opposing party $($ Same Party $=0)$ and fall into the interactive category for the dominant party and non-partisan elections (SP*Non-Partisan $=1$ ). The predicted probabilities are estimated using the SPost commands developed by J. Scott Long and Jeremy Freese (2001).

${ }^{14}$ The fully specified hypothetical observation sets Unanimous $=1$, PAJID $=48.33$, and all other observations to zero (0). 


\section{REFERENCES}

Atkins, Burton M. and Henry R. Glick. 1976. Environmental and Structural Variables as Determinants of Issues in State Courts of Last Resort. American Journal of Political Science 20:97-115.

Berry, William D. Evan J. Ringquist, Richard C. Fording, and Russell L. Hanson. 1998. Measuring Citizen and Government Ideology in the American States, 1960-93. American Journal of Political Science 42:327-348.

Beck, Nathaniel. 1996. Reporting Heteroskedasticity-Consistent Standard Errors. The Political Methodologist 7:4-6.

Bibby, John F. and Thomas M. Holbrook. 1999. Parties and Elections. In Politics in the American States: A Comparative Analysis, eds. Virginia Gray, Russell L. Hanson, Herbert Jacob. Washington, DC: CQ Press.

Brace, Paul and Melinda Gann Hall. 1990. Neo-Institutionalism and Dissent in State Supreme Courts. Journal of Politics 52:54-70.

Brace, Paul and Melinda Gann Hall. 1997. The Interplay of Preferences, Case Facts, Context, and Rules in the Politics of Judicial Choice. Journal of Politics 59:1206-1231.

Brace, Paul and Melinda Gann Hall. 2001. The State Supreme Court Data Project. November. http://www.ruf.rice.edu/ pbrace/statecourt/.

Brace, Paul, Laura Langer, and Melinda Gann Hall. 2000. Measuring the Preferences of State Supreme Court Justices. Journal of Politics 62:387-413.

Bush v. Gore. 2000. 531 U.S. 98.

Canon, Bradley C. and Michael Giles. 1972. Recurring Litigants: Federal Agencies Before the Supreme Court. Western Political Quarterly 25:183-191.

Coglianese, Cary. 1998. Legal Change at the Margins: Revisiting the Political Disadvantage Theory. Harvard University Kennedy School of Government Working Paper.

Cortner, Richard C. 1968. Strategies and Tactics of Litigants in Constitutional Cases. Journal of Public Law 17:287-307.

Epstein, Lee and Charles D. Hadley. 1990. On the Treatment of Political Parties in the U.S. Supreme Court, 1900-1986. Journal of Politics 52:413-432.

Gillman, Howard. 2001. The Votes That Counted. Chicago: University of Chicago Press.

Glick, Henry R. 1991. Policy Making and State Supreme Courts. In The American Courts: A Critical Assessment, ed. John B. Gates and Charles A. Johnson. Washington, DC: CQ Press.

Glick, Henry R. 1999. Courts: Politics and the Judicial Process. In Politics in the American States: A Comparative Analysis, ed. Virginia Gray, Russell L. Hanson, Herbert Jacob. Washington, DC: CQ Press.

Greene, William H. 2000. Econometric Analysis. Upper Saddle River, NJ: Prentice Hall.

Hall, Melinda Gann. 2001. State Supreme Court in American Democracy: Probing the Myths of Judicial Reform. American Political Science Review 95:315-330.

Hamm, Keith E. and Gary F. Moncrief. 1999. Legislative Politics in the States. In Politics in the American States: A Comparative Analysis, ed. Virginia Gray, Russell L. Hanson, Herbert Jacob. Washington, DC: CQ Press.

Lloyd, Randall D. 1995. Separating Partisanship from Party in Judicial Research: Reapportionment in the U.S. District Courts. American Political Science Review 89:413-420.

Long, J. Scott and Jeremy Freese. 2001. Regression Models for Categorical and Limited Dependent Variables. College Station, TX: Stata Press.

Mason, Alpheus. 1956. Harlan Fiske Stone: Pillar of the Law. New York: Viking Press. 
McCleskey, Clifton. 1984. Parties at the Bar: Equal Protection, Freedom of Association, and the Rights of Political Associations. Journal of Politics 46:346-68.

Olson, Susan M. 1990. Interest-Group Litigation in Federal District Court: Beyond the Political Disadvantage Theory. Journal of Politics 52:854-82.

Pritchett, C. Herman. 1948. The Roosevelt Court. New York: Macmillan.

Ranney, Austin. 1976. Parties in State Politics. In Politics in the American States: A Comparative Analysis, eds. Herbert Jacob and Kenneth Vines. Boston: Little, Brown.

Schubert, Glendon A. 1965. The Judicial Mind. Evanston, IL: Northwestern Univ. Press.

Segal, Jeffrey A. and Harold J. Spaeth. 1993. The Supreme Court and the Attitudinal Model. New York: Cambridge University Press.

Sheehan, Reginald S., William Mishler, and Donald R. Songer. 1992. Ideology, Status, and the Differential Success of Direct Parties before the Supreme Court. American Political Science Review 86:464-471.

Sheppele, Kim Lane and Jack L. Walker, Jr. 1991. The Litigation Strategies of Interest Groups. In Mobilizing Interest Groups in America: Patrons, Professions, and Social Movements, ed. Jack L. Walker, Jr. Ann Arbor: University of Michigan Press.

Songer, Donald R. and Sue Davis. 1990. The Impact of Party and Region on Voting Decisions in the United States Courts of Appeals, 1955-1986. Western Political Quarterly 43:317-334.

Songer, Donald R. and Reginald S. Sheehan. 1992. Who Wins on Appeal? Upperdogs and Underdogs in the United States Courts of Appeals. American Journal of Political Science 36:235-258.

Tate, C. Neal. 1981. Personal Attribute Models of the Voting Behavior of U.S. Supreme Court Justices: Liberalism in Civil Liberties and Economics Decisions, 1946-1978. American Political Science Review 75:355-367. 
